\title{
Leren helen
}

Citation for published version (APA):

Teunissen, P. (2018). Leren helen. Maastricht University. https://doi.org/10.26481/spe.20180202pt

Document status and date:

Published: 02/02/2018

DOI:

10.26481/spe.20180202pt

Document Version:

Publisher's PDF, also known as Version of record

\section{Please check the document version of this publication:}

- A submitted manuscript is the version of the article upon submission and before peer-review. There can be important differences between the submitted version and the official published version of record.

People interested in the research are advised to contact the author for the final version of the publication, or visit the DOI to the publisher's website.

- The final author version and the galley proof are versions of the publication after peer review.

- The final published version features the final layout of the paper including the volume, issue and page numbers.

Link to publication

\footnotetext{
General rights rights.

- You may freely distribute the URL identifying the publication in the public portal. please follow below link for the End User Agreement:

www.umlib.nl/taverne-license

Take down policy

If you believe that this document breaches copyright please contact us at:

repository@maastrichtuniversity.nl

providing details and we will investigate your claim.
}

Copyright and moral rights for the publications made accessible in the public portal are retained by the authors and/or other copyright owners and it is a condition of accessing publications that users recognise and abide by the legal requirements associated with these

- Users may download and print one copy of any publication from the public portal for the purpose of private study or research.

- You may not further distribute the material or use it for any profit-making activity or commercial gain

If the publication is distributed under the terms of Article $25 \mathrm{fa}$ of the Dutch Copyright Act, indicated by the "Taverne" license above, 
Prof. dr. Pim Teunissen

Faculty of

Health, Medicine and Life Sciences

\section{Leren Helen}




\section{Leren helen}

Prof. dr. Pim Teunissen

Rede uitgesproken bij de aanvaarding van het ambt van bijzonder hoogleraar 'Werkplekleren in de Gezondheidszorg' aan de Faculty of Health, Medicine and Life Sciences van de Universiteit Maastricht.

Geachte rector magnificus, college van bestuur, decaan, vice decaan en andere leden van het faculteitsbestuur FHML, College van Toezicht en beste collega's, familie en vrienden, welkom in mijn wereld. Als u hier naartoe bent gekomen om te begrijpen waar ik me in mijn onderzoek mee bezig houd, dan start dat met nu eens goed om $u$ heen kijken. $U$ ziet dan de mensen waar ik mee samenwerk. Medisch specialisten, verpleegkundigen, verloskundigen, huisartsen, mensen in opleiding voor deze vakken, onderwijskundigen, psychologen, beleidsmedewerkers, secretaresses. Dat is een greep uit de variatie aan mensen waar ik mee samenwerk om ervoor te zorgen dat we nu en in de toekomst goede zorg hebben.

Die toekomst brengt ongetwijfeld meer indrukwekkende technologische ontwikkelingen en toename van medische kennis. Desondanks is en blijft gezondheidszorg is mensenwerk. Mensen die voldoening halen uit het helpen en er zijn voor andere mensen. Daarom is een belangrijk onderwerp, één die altijd actueel zal blijven: hoe leidt je deze mensen zo goed mogelijk op? Wat moet je een verpleegkundige in opleiding, geneeskunde student of bijna afgestuurde fysiotherapeut, vandaag meegeven om de kans zo groot mogelijk te maken dat ze gedurende hun gehele loopbaan goed en met plezier kunnen blijven functioneren?

Dat is een uitdaging, want niemand weet precies hoe onze zorg er over 20 of 30 jaar uitziet, welke nieuwe ziektes dan misschien de kop op hebben gestoken, wat we dan kunnen. Als gynaecoloog werk ik nu met kennis en technische mogelijkheden die niet bestonden toen ik mijn geneeskunde opleiding volgde, bijvoorbeeld als het gaat over wat we tijdens de zwangerschap met een echo kunnen zien of onderzoek in het bloed van moeder naar chromosoomafwijkingen bij een ongeboren kind. Om als zorgverlener goed je werk te kunnen blijven doen, zal je moeten blijven ontwikkelen, blijven leren. Goede zorg en opleiden voor goede zorg is dus nooit af, daar moeten we aan blijven werken. Dat is wat medisch onderwijs doet. De uitdaging voor het onderzoeksgebied medisch onderwijs is om te leren van het verleden, reageren op het heden en anticiperen op de toekomst.

Ik heb het vandaag over het opleiden van zorgverleners. En dat raakt ons allemaal. Vroeg of laat komen we allemaal als patiënt of als partner of ouder van een patiënt met de zorg in aanraking en dan willen we zo goed mogelijk worden geholpen. Dat is de reden waarom de vraag 'hoe bereiden we zorgverleners voor op een onzekere toekomst' mij blijft motiveren. Het gaat om de mensen die ik wekelijks op mijn poli zie, zoals een zwangere twee weken geleden. In de vorige zwangerschap was haar kind onverwacht in de buik overleden, net voordat ze zou bevallen. Ze was nu opnieuw zwanger en behalve blij vooral angstig. Ze vroeg me ervoor te zorgen dat haar huidige zwangerschap goed zou aflopen. Het gaat om haar, het gaat om $u$, wanneer u met een probleem naar de huisarts gaat. Om uw kind of moeder, om onze familie en vrienden. 
De vraag is dus: hoe bereiden we onze zorgverleners voor op een onzekere toekomst? Ik zeg bewust voorbereiden, want dat is breder dan de opleidingen die we aanbieden. In deze voorbereiding speelt onderwijs uiteraard wel een rol, maar al tijdens de opleiding tot verpleegkundige, of verloskundige, of arts vindt het meeste leren plaats op het werk, door te werken, door meer of minder begeleid bij te dragen aan zorg voor patiënten. ${ }^{1}$ Werkplekleren is de term die dit omvat. Werkplekleren is divers, van de chirurg die uitleg geeft aan een jonge co-assistent over het hechten van wonden in het gezicht, tot verpleging op de verloskamers die een enthousiaste arts-assistent duidelijk maakt dat ze beter moet prioriteren. Het gaat over de eerste keer dat ik alleen een keizersnede deed als gynaecoloog in opleiding en de eerste keer dat ik het iemand anders alleen liet doen onder mijn verantwoordelijkheid. Allemaal werkplekleren. Leren door en van je werk, in welke fase van je carrière je ook zit, hoort bij werken in de zorg.

Of je in de zorg nu een $\mathrm{MBO}, \mathrm{HBO}$, universitaire opleiding of een vervolgopleiding tot specialist volgt, je leert al doende. En wanneer de structuur die door een opleiding geboden wordt verdwijnt houdt het leren niet op. Bijvoorbeeld als je de opleiding tot specialist afrondt, vaak 10 tot 15 jaar nadat je de geneeskunde opleiding begon, zijn er weer nieuwe aspecten die je moet ontwikkelen. Door onderzoek van Michiel Westerman, de eerste promovendus waar ik als begeleider bij betrokken was, weten we dat nieuwe specialisten aanlopen tegen de managementtaken die ze krijgen en financiële kanten van een eigen praktijk runnen. We hebben onderzocht hoe ze dit soort zaken leren. ${ }^{2}$

Dit voorbeeld illustreert het type onderzoek dat ik doe. Ik neem geen genoegen met 'je leert het al doende'. Ik wil weten hoe dat dan precies gaat. Begrijpen welke ervaringen op welke manier bijdragen aan de ontwikkeling van zorgverleners. Hoe interpreteert iemand wat hij of zij meemaakt, welke informatie gebruiken ze daarbij? ${ }^{3}$ Door te werken als zorgverlener wordt duidelijk wat je moet weten, kunnen en doen om goed te functioneren. Dat leerproces blijkt altijd een samenspel tussen individu en omgeving. Wat ik met onderzoek probeer te doen is de vragen te stellen die helpen om dit soort leren te herkennen en begrijpen. ${ }^{4}$

Toen Michiel aan zijn onderzoek begon was er in de praktijk wel het besef dat het lastig kon zijn als nieuwe specialist te starten. Maar onderzoek ernaar ontbrak.

Een groot deel van het onderzoek dat ik begeleid gaat over het doorgronden van hoe ons werk ons dwingt én helpt te leren van wat we doen. Dit vind ik belangrijk omdat naar mijn mening dit begrip van hoe zorgverleners leren door te werken de basis is voor het ondersteunen en verbeteren van dat leren. Een deel van wat zorgverleners al doende leren kan beter, efficiënter of veiliger voor lerende en patiënt. En er zijn zaken die anders moeten, bijvoorbeeld slechte gewoontes in hoe we met patiënten en elkaar omgaan en onzinnige variatie in de behandeling van vergelijkbare patiënten. ${ }^{5,6}$ Hier kunnen we onderwijskundige inzichten over gedragsverandering, leren en toetsen bij gebruiken. En dat is het andere onderwerp op mijn onderzoeksagenda; hoe zorgen we ervoor dat onderwijskundige inzichten aansluiten bij werkplekleren?

Een voorbeeld hiervan is het onderzoek van Chris Rietmeijer naar observatie. Vanuit de onderwijskunde is het advies om de lerende veel te observeren want dan kan je concrete feedback geven. In de praktijk wordt, zeker door meer ervaren mensen in opleiding, observatie vaak als een teken van wantrouwen ervaren. Chris brengt dit spanningsveld in kaart om vervolgens beter te begrijpen hoe we leren op de werkplek kunnen verbeteren.

De kern van mijn onderzoeksagenda is dus enerzijds begrijpen hoe zorgverleners leren van het werk dat ze doen én anderzijds onderzoeken hoe opleidingen leren optimaal kunnen ondersteunen. Deze agenda voor onderzoek sluit aan bij mijn visie op werkplekleren in de zorg. Onder andere door de resultaten van het onderzoek waar ik aan heb bijgedragen heeft die visie zich ontwikkeld. Ik ga mijn visie met u delen als achtergrond voor mijn onderzoeksagenda. 
Het dominante systeem voor opleidingen in de gezondheidszorg is competentiegericht onderwijs. Sinds eind vorige eeuw heeft dit zijn weg gevonden naar opleidingen in de zorg. ${ }^{7}$ Toen ik startte met mijn promotieonderzoek, in 2005, was Fedde Scheele, mijn $1^{\mathrm{e}}$ promotor, bezig de laatste hand te leggen aan het eerste competentiegerichte opleidingsplan voor een medisch specialistische vervolgopleiding in Nederland, de opleiding tot gynaecoloog. ${ }^{8}$ Meer mensen die aan de bakermat hebben gestaan van de beweging naar competentiegerichte zorgopleidingen in Nederland zijn hier aanwezig. Vandaag is een goed moment om de balans op te maken. We zijn namelijk op het punt aangekomen dat er steeds meer onderzoek beschikbaar komt over hoe competentiegericht opleiden in de zorg uitpakt. Ik heb zelf aan verschillende studies bijgedragen, bijvoorbeeld via het promotieonderzoek van Joanna Fokkema, Harold Bok en Karsten van Loon. ${ }^{9-11}$ Uit dat onderzoek komen zaken naar voren die goed gaan maar ook dat onze goede onderwijsbedoelingen leren van het werk in de weg kunnen staan. De afgelopen jaren hebben ertoe geleid dat er meer aandacht is voor opleiden en leren. Maar er zijn onderwijskundig goede ideeën over leerdoelen formuleren, goede feedback inbouwen en toetsing waar we bij herhaling op vastlopen.

Ik ga $\mathrm{u}$ uitleggen dat het tijd is om de koers te verleggen. Dat start met inzicht in een tegenstrijdigheid die ik de paradox van competentiegericht opleiden noem. Vervolgens stel ik een toekomstrichting voor, één waarbij we ons moeten richten op afstemming tussen werken en leren in de zorg.

\section{De paradox van competentiegericht opleiden}

Ik heb een vraag voor degenen die na de basisschool nog een opleiding hebben gevolgd, een beroepsopleiding of een universitaire opleiding.

Wie van $u$ is competentiegericht opgeleid?

Sinds het begin van de $21^{\mathrm{e}}$ eeuw zijn de meeste beroepsopleidingen en dus ook opleidingen in de zorg en óók de universitaire opleidingen tot arts, competentiegericht. Voor diegenen die zelf competentiegericht zijn opgeleid is het waarschijnlijk lastig voor te stellen hoe een opleiding er anders uit zou kunnen zien. Degenen die nooit een competentiegerichte opleiding hebben gevolgd, kunnen zich ongetwijfeld moeilijk voorstellen hoe dat zo anders is dan wat ze zelf hebben meegemaakt in het onderwijs.

Competentiegericht opleiden is niet een uitvinding die als donderslag bij heldere hemel tot ons is gekomen. Het is het resultaat van een ontwikkeling die zich in verschillende beroepsopleidingen en in verschillende landen net iets anders heeft voltrokken. ${ }^{12}$ Hoe komt het dan dat we competentiegericht zijn gaan opleiden in de zorg? Het verhaal achter de CanMEDS is hier een goede illustratie van. CanMEDS staat voor Canadian Medical Education Directives for Specialists. ${ }^{13}$ Het is de naam van het competentieraamwerk dat beschrijft wat de uitkomsten moeten zijn van de opleiding tot specialist. Het komt oorspronkelijk uit Canada en wordt nu in veel meer landen gebruikt. In Nederland is het de basis voor verschillende opleidingen in de zorg, bijvoorbeeld die tot verpleegkundige, verloskundige, basisarts en medisch specialist.

Op 12 juni 1986 zijn artsen in de Canadese provincie Ontario gaan staken uit protest tegen plannen van de provinciale regering om de gezondheidszorg te hervormen. ${ }^{14}$ De staking duurde 25 dagen, de langste in de zorg in de geschiedenis van Canada. Het ging over geld, artsen vonden dat ze de mogelijkheid moesten houden om extra te kunnen declareren bovenop het afgesproken basistarief. Het resultaat was veel kwaad bloed bij publiek en politiek. De staking werkte averechts en de nieuwe wet werd aangenomen. De medische beroepsgroep was verrast over hoe weinig steun ze kregen vanuit de maatschappij en realiseerde zich dat er een groot gat zat tussen hoe de medische professie over zichzelf dacht en hoe het publiek over hen dacht. 
Als gevolg hiervan zijn in 1990 de 5 medische opleidingen in Ontario een gezamenlijk project gestart om het medisch onderwijs zodanig te verbeteren dat het beter aan zou sluiten bij wat de maatschappij verwacht. Dit project heette 'Educating Future Physicians for Ontario'. ${ }^{15}$ Kort samengevat maakte het project in Ontario heel duidelijk dat zowel het publiek als zorgverleners ontevreden waren over de wijze waarop werd omgegaan met patiënten. ${ }^{15}$

- Je wilt als mens benaderd en geholpen worden en niet als een geval.

- Ze misten duidelijke communicatie, artsen moesten meer tijd nemen om vragen te beantwoorden en duidelijke uitleg te geven.

- Men verwachtte beter van zorgverleners - om gezien te worden als medemens.

Als je in het ziekenhuis ligt wil je niet 'het gebroken been in kamer 3' zijn, of 'die longontsteking bij het raam'.

De ervaring van patiënten en zorgverleners was dat de toename van technologie, kennis en specialisatie, eraan bijdroegen dat er sprake was van toenemende objectificatie. Ziekte als het haperen van de menselijke machine, een kapot onderdeel dat gemaakt moet worden, de mens om wie het gaat wordt een object. Wat scheelt er aan de menselijke machine, hoe sporen we dat op en hoe repareren we de machine weer? De zorg als autogarage. Dat speelde toen en dat is nu nog net zo actueel. Met nieuwe genetische testen, nieuwe operatietechnieken, nieuwe medicijnen zíjn we ook aan het sleutelen aan het lijf, zien we ziekte graag als een geïsoleerd probleem en is het risico van objectificatie in de zorg zeker niet afgenomen. Daarin voeden we elkaar, zorgsector en publiek, met de geruststellende gedachte dát het inderdaad zo werkt. Als je ziek bent ga je naar de dokter en die MAAKT je beter.

Maar zo werkt het zo niet. Wat er scheelt aan het lijf en wat dat voor iemand betekent, hoe ze er mee omgaan en hoe je een ander mens kan helpen in zo'n situatie vraagt om een andere insteek. Ziekte, van een infectie tot depressie en van zwangerschapsvergiftiging tot een gebroken arm, verstoort het evenwicht in je leven, niet alleen in een onderdeel van je lijf. De impact van die verstoring verschilt van persoon tot persoon. ${ }^{16}$ Dit sluit aan bij de titel van mijn oratie. Leren helen. Helen komt van heel, weer heel worden, het gevoel hebben weer compleet te zijn, je balans terug te vinden. Wij, als zorgverleners, MAKEN iemand niet beter. Om iemand te helpen zich na ziekte of verlies weer 'heel' te voelen, bieden we hulp door een gesprek, door er te zijn, soms met medicijnen of door te opereren. Al kunnen we de oorzaak van het probleem wegnemen, we kunnen er niet voor zorgen dat iemand zijn of haar evenwicht hervindt. De persoon om wie het gaat zit in een proces, dat altijd ook sociale en emotionele kanten heeft. Zorgverleners moeten leren wat het vergt om bij te dragen aan opnieuw heel worden, leren helen.

Dit is niet makkelijk. Wij zorgverleners zijn allemaal, ook ik en ook jullie, geneigd om van mensen medische problemen te maken. Wij bedenken welk label het probleem krijgt, zoeken de passende richtlijn erbij en leggen uit op welk behandelplan het probleem tegenover ons kan rekenen. Een consult van 10 minuten of een kwartier leent zich slecht voor een gesprek over de impact van wat er speelt op iemands leven. Bovendien vraagt zo'n benadering veel van je als zorgverlener. Je moet je openstellen, inleven, je raakt betrokken, daar moet je mee om kunnen gaan.

De gedachte dat een goede zorgverlener meer is dan medische kennis en vaardigheden is verwerkt in de uitkomsten van het project in Ontario. En dat regionale project was de basis voor het landelijke CanMEDS project. Het CanMEDS competentie raamwerk bestaat uit 7 competentiegebieden. Centraal staat medische expertise. Maar vanuit de erkenning dat er meer nodig is voor een goede zorgverlener zijn daaraan toegevoegd: communicatie, samenwerking, leiderschap, wetenschap, maatschappelijk handelen en professionaliteit. ${ }^{13}$ Dit model is dus dé manier waarop we het gevaar van objectificatie in de zorg tegen proberen te gaan. Competentiegericht opleiden is een bescherming, een antidotum, tegen objectificatie in de zorg. 
Deze 7 competentiegebieden maken nog geen opleidingsplan. Om vanuit algemene competentiegebieden tot een opleidingsplan komen voor een arts of verpleegkundige is voor elk van deze gebieden gedetailleerd uitgewerkt wat iemand moet kunnen in verschillende fasen van de opleiding. En hierdoor is er een paradox ontstaan, een schijnbare tegenstelling. De manier waarop we tegenwoordig opleiden is ten prooi gevallen aan de objectificatie die het moest voorkomen.

Ik ga het uitleggen aan de hand van het competentiegebied communicatie uit de 2015 versie van de CanMEDS. ${ }^{17}$ De omschrijving daarvan luidt: zorgverleners zijn in staat relaties aan te gaan met patiënten en hun families die het mogelijk maken om essentiële informatie voor effectieve zorg te verkrijgen en te delen. Mooie algemene omschrijving, past bij het bijdragen aan heel worden wat we van zorgverleners verwachten. Maar als we iemand opleiden willen we ook helder afspreken wanneer diegene toe is aan meer verantwoordelijkheid. Wanneer verdient iemand een diploma zodat ze zelfstandig aan de slag kunnen? We willen omschrijvingen van leeruitkomsten die we kunnen toetsen.

Dit is een belangrijk aspect dat bij het huidige competentiegerichte opleiden hoort; het is outcome-based, of uitkomst-georiënteerd, opleiden., ${ }^{73} \mathrm{De}$ vertaalslag van algemene naar specifieke omschrijvingen is opgelost door binnen elk van de 7 competentiegebieden verschillende kerncompetenties te benoemen. Voor communicatie zijn dat er 5 . En elke kerncompetentie heeft dan weer 'enabling competencies'. Een mooie vertaling daarvan is lastig, wat daarmee bedoeld wordt is hetgeen je daadwerkelijk moet kunnen. Een voorbeeld voor 'communicatie' is dat je patiëntcontact nauwkeurig, compleet, op tijd en op een toegankelijke manier moet vastleggen, passend binnen de voor jou geldende relevante weten regelgeving op dit gebied. Voor communicatie zijn er in totaal 17, alles bij elkaar zijn er 89 'enabling competencies'. Voordat je denkt dat dit het is, er zijn verschillende prestatie-eisen gesteld binnen een 'enabling competency'. Wat een beginner moet kunnen is anders dan iemand aan het einde van een opleiding moet kunnen. Zo zijn er dan weer zes niveau's beschreven en per niveau soms wel 3 of 4 uitkomstomschrijvingen. Er zijn er echter ook waar het onderwerp blijkbaar belangrijk gevonden werd, maar de 'enabling competency' toch lastig concreet te maken was. Ik heb ze allemaal voor u geteld, het zijn er in totaal 637. Er zijn dus 7 competentiegebieden, 27 kerncompetenties, 89 'enabling competencies' en die resulteren in 637 uitkomstomschrijvingen van wat een zorgverlener in opleiding in verschillende fasen moet kunnen.

Dat is dan het algemene raamwerk, dat nog moet worden uitgewerkt in een specifiek opleidingsplan voor een verpleegkundige opleiding of specialisme. Die moeten allemaal getoetst worden, op de werkplek in meerdere situaties en door verschillende begeleiders zodat het gemiddelde oordeel redelijk betrouwbaar is. Ik gebruik de CanMEDS 2015 als voorbeeld. Op veel plekken wordt nog een oudere versie gehanteerd of een iets ander algemeen raamwerk met wellicht minder ver uitgewerkte uitkomstomschrijvingen. Toch zien we dat het resultaat, wat uit onderzoek komt in Nederland maar ook in Canada en het Verenigd Koninkrijk, is dat veel opleidingen in de praktijk lijken op een afvinklijst. ${ }^{18-21} \mathrm{Al}$ willen we dat niet en hoor je regelmatig slogans als 'niet vinken maar vonken' en proberen we in cursus voor opleiders vooral het achterliggende idee van de competentiegebieden te benadrukken. Het is eigenlijk een logisch gevolg van de manier waarop we competentiegerichte opleidingen ontwikkelen, van algemene gebieden naar honderden omschrijvingen van specifieke leeruitkomsten. Voorheen deden we dat met kennisgebieden, nu met competenties. Er zijn slimme manieren om dit meer behapbaar te maken, zoals het beoordelen van verschillende van die leeruitkomsten binnen één activiteit (ook wel aangeduid met de term EPA) ${ }^{22}$ Het onderliggende probleem blijft echter bestaan. Dat we opleidingen maken door gedetailleerd een groot aantal leeruitkomsten te beschrijven die samen een complete zorgverlener moeten opleveren. ${ }^{23}$

Als we nu de balans opmaken dan vraag ik me af of competentiegericht opleiden in de zorg, bijna 30 jaar nadat deze beweging op gang kwam, het tij van toenemende objectificatie in de 
zorg heeft kunnen keren? Wat in ieder geval duidelijk is, is dat opleidingen in de gezondheidszorg inmiddels aan hetzelfde probleem van objectificatie leiden. Het resultaat van opleiden is een product, een competente zorgverlener. Als je bij al de 637 leeruitkomsten een vinkje hebt staan ben je klaar met je opleiding. Dat is de paradox van competentiegericht opleiden in de zorg, in de kern een antidotum tegen het risico van objectificatie, maar zelf ten prooi gevallen aan hetgeen het probeert te voorkomen.

Het is tijd om de koers te verleggen. Geen totale breuk met het verleden, maar het moet wel anders. Om te begrijpen hoe anders, moeten we af van een hardnekkig idee dat ten grondslag ligt aan onze zorgopleidingen. Het idee dat goede zorg ontstaat wanneer je individuen opleidt tot goede zorgverleners en dat een goede zorgverlener het resultaat is van 637 afgevinkte gedragsomschrijvingen. Ik noem dat de Lego-aanpak. Allemaal losse blokjes, verschillend van vorm en kleur en alles bij elkaar bouw je een complete Lego-zorgverlener. Zet ze bij elkaar en je hebt goede zorg. Deze aanpak heeft iets aantrekkelijks, uit onderzoek door Karsten van Loon blijkt dat zelfs een deel van de zorgverleners denken dat het zo werkt.

Dat een individu die iets niet goed doet ervoor kan zorgen dat er dingen flink fout gaan is waar. Maar dat mag je niet omdraaien en denken dat als iedereen goed is opgeleid en zijn competenties heeft laten afvinken dat dan alles goed zal gaan. Een competent individu is niet een optelsom van afgevinkte competenties. En zoiets complex als goede zorg is geen optelsom van competente individuen. Om als collectief goed te functioneren zijn onderlinge relaties, verwachtingen, van elkaar willen en kunnen leren, routines, afspraken en coördinatie essentieel. $\mathrm{Er}$ is inmiddels veel onderzoek wat dit duidelijk maakt. Bijvoorbeeld van de groep van Lorelei Lingard uit Canada en door het werk van Tim Dornan uit Noord-lerland. ${ }^{24,25}$ Ook uit gezamenlijk onderzoek dat ik met hen doe komt het inzicht dat goede zorg het resultaat is van een collectief proces. In de literatuur wordt dit het beste samengevat door de term 'collective competence'.

Een voorbeeld, een paar weken geleden had ik dienst en moesten we met spoed een keizersnede doen. De zwangere, die zelf een angststoornis had en waarvan de partner alleen Indonesisch en gebrekkig Engels sprak, werd begeleid door een verpleegkundige en een klinisch verloskundige. Plots begon ze te bloeden, vaginaal bloedverlies, en het hartfilmpje van de baby zag er niet goed uit. De arts-assistent is erbij geroepen en samen kwamen ze snel tot het besluit dat er met spoed een keizersnede nodig was. Het vermoeden was dat de placenta los was gekomen van de wand van de baarmoeder. Ze belden mij, ik bevestig dat we met spoed een keizersnede moeten doen en samen moeten we regelen dat patiënte binnen een paar minuten op de operatiekamers is, klaar om geopereerd te worden. De arts-assistent belt de kinderarts dat ze naar de operatiekamers moeten komen. Ik bel de anesthesie dat we met spoed willen opereren. De anesthesist informeert zijn anesthesie-medewerker en de operatie assistenten. De verpleegkundigen zijn inmiddels onderweg naar de operatiekamers, terwijl de verloskundige partner probeert bij te praten. Onze baliemedewerker zorgt dat de lift richting de operatiekamers wordt vastgehouden. Al onze systemen, van lift tot infuuspomp tot elektronisch ziekenhuis systeem moeten goed werken.

Dan heb ik het alles bij elkaar zo over 15 verschillende mensen, inclusief patiënt en partner, die in een tijdsbestek van 5 minuten moeten zorgen dat we een spoedkeizersnede kunnen doen. Om dat alles goed te laten gaan zijn individuele processen van belang, zoals de initiële afweging dat er een keizersnede nodig was door de verloskundige, individuele uitkomsten, zoals de anesthesist die een zwangere in spoedsetting kan intuberen (een beademingsbuis in de keel krijgt), en het collectieve proces van hoe wij met elkaar informatie uitwisselen en coördineren wie wat doet. Dat leidt tot de collectieve uitkomst dat er uiteindelijk een dochter met een goede start geboren wordt en moeder na de operatie zonder complicaties weer wakker wordt om haar kind voor het eerst te zien. 
Kortom, goede zorg is teamwerk. Maar onze huidige opleidingen werken met een insteek die gebaseerd is op individuele competenties. We leiden individuen op, suggereren dat competenties als samenwerken, communiceren en organiseren individuele kwaliteiten zijn en hechten vooral waarde aan individuele uitkomsten van leren door dat als leerdoelen te verheffen. Helaas sluit dat onvoldoende aan bij hoe we werken in de zorg en wat zorg goed maakt.

\section{Naar afstemming en verbinding tussen werken en leren in de zorg}

De uitdaging is dus tweeledig. Om met alle kennis en technische mogelijkheden die we hebben, de mensen voor wie we het doen te helpen in hun complexe proces van helen. En om ervoor te zorgen dat opleidingen in de zorg aansluiten bij de praktijk door te onderkennen dat goede zorg een samenspel is van individu en collectief. Een goede zorgverlener heeft zeker up-to-date medische kennis, moet, afhankelijk van het vakgebied, technisch vaardig zijn en is daarnaast in staat dat in te zetten in een complexe omgeving om samen met anderen bij te dragen aan het unieke proces waarin een patiënt op weg is naar het vinden van een nieuw evenwicht. Hoe we dat moeten doen? We hebben een opleiding nodig die aandacht heeft voor uitkomst en proces van het leren én een opleiding die erkent dat sommige uitkomsten en processen meer bij het individu liggen en andere meer bij het collectief.

Dan ziet u nu ook hoe mijn onderzoeksagenda hierbij past. Met mijn onderzoek draag ik bij aan inzicht in hoe zorgverleners leren van het werk dat ze doen én hoe een opleiding dat leren optimaal kan ondersteunen. Daaruit komen het belang van het leerproces en van leeruitkomsten en van meer aandacht voor bijdragen aan het collectief. ${ }^{4}$ Aan het begin heb ik u gewezen op de variatie aan mensen waar ik mee samenwerk. Het is u nu hopelijk duidelijk waarom dat zo is. Mijn onderzoeksagenda vraagt om verschillende perspectieven, van zorgverleners en onderwijsmensen uit de praktijk, en van onderzoekers uit verschillende onderzoeksvelden.

Onderzoek en kennis over hoe leren in de praktijk gaat is de basis. Ik ga u ook schetsen hoe we dat in kunnen zetten voor een andere wijze van opleiden. Ik wil namelijk af van het legomodel, starten met 7 algemene competenties en dat steeds verder uitwerken tot 637 toetsbare leeruitkomsten. In plaats van competency-based medical education stel ik 'work-based medical education' voor. Voor het praktijkgedeelte van zorgopleidingen. Dat is opleiden met aandacht voor ontwikkeling op drie niveaus, waarin we expliciet maken dat niet alleen leeruitkomsten maar ook leerproces telt. Het eerste niveau van ontwikkeling zijn individuele en context-specifieke kennis en vaardigheden. Het tweede niveau richt zich op werk-gerelateerde competenties en ik zal zo definiëren wat ik daarmee bedoel. Het derde niveau is de meer individuele ontwikkeling van de zorgverlener als mens.

Van niveau 1 naar 3 vindt een verschuiving plaats van focus op leeruitkomsten naar focus op leerproces. Kennis en vaardigheden moeten we streng toetsen op leeruitkomsten, wat je moet weten en kunnen. Niveau 2, werk-gerelateerde competenties vragen om aandacht voor zowel toetsbare leeruitkomst als leerproces. Niveau 3, de ontwikkeling van de zorgverlener als mens kent vooral een focus op leerproces.

Voor het eerste niveau moeten we per opleiding bepalen over welke kennis en vaardigheden iemand in welke fase van een opleiding moet beschikken. Welke anatomische kennis moet je hebben voordat je als co-assistent een lichamelijk onderzoek op een patiënt uitvoert? Hoe goed moet je zijn in een simulatie voordat je bij een echte operatie mag assisteren? Het gaat hier niet om context-loze feitjes of simpele trucjes. Het zijn kennis en vaardigheden verbonden aan de taken die je op je werkplek uitvoert. ${ }^{26,27}$ Als we basiswetenschappers, curriculumbouwers en mensen uit de praktijk bij elkaar zetten, komen we waarschijnlijk al een heel eind met de omschrijving voor verschillende opleidingen en verschillende fasen. Ook kunnen we op dit niveau goed en eerlijk toetsen, bijvoorbeeld met kennistoetsing, in toets stations en met simulaties. ${ }^{28}$ Dus, in plaats van alles te willen vangen in competenties, pleit ik 
ervoor om als het over kennis en vaardigheden gaat het ook zo te noemen en die hard te toetsen op uitkomst.

Niveau twee is een grotere uitdaging. Ik heb u uitgelegd dat goede zorg teamwerk is. Hiervoor zijn zaken als samenwerking, communicatie, onderlinge afstemming en het vermogen om te blijven leren van belang. De meer algemene competentiegebieden en kerncompetenties uit een competentieraamwerk zoals de CanMEDS helpen om te herkennen wat van belang is. Welke competenties van belang zijn is wel afhankelijk van het vakgebied waar je in werkt. Harold Bok heeft in zijn promotieonderzoek binnen de diergeneeskunde een aangepast competentieraamwerk ontwikkeld, om het beter aan te laten sluiten bij het werk van een afgestuurde dierenarts. ${ }^{29}$ Zo moeten we ook in de zorg nagaan welke competenties aandacht moeten krijgen. Teamwerkcompetenties mogen naar mijn mening meer benadrukt worden.

Als ik het heb over competenties in het kader van de opleiding van een individuele zorgverlener, dan bedoel ik daarmee: de kwaliteiten hebben om als zorgverlener bij te kunnen dragen aan een goede uitkomst van een situatie in de zorg. Er zijn wetenschapsgebieden die duidelijk maken wat je vooral wel en vooral niet moet doen om constructief bij te dragen aan goede zorg. ${ }^{30}$ Een deel van wat we van een individu mogen verwachten gaat over toetsbare leeruitkomsten. Veel minder dan de 637 uit de CanMEDS en meer toegespitst op het specifieke werk dat iemand moet doen. Wanneer iemand de kans en begeleiding krijgt zich op deze vlakken te ontwikkelen en dat uit de weg gaat of toch telkens voor de optie kiest die het functioneren van een het team ontwricht, dan is dat onacceptabel. Denk aan het typische voorbeeld van de chirurg die gaat schreeuwen als het niet gaat zoals hij wil.

Om als opleiding daadwerkelijk bij te dragen aan leren en ontwikkeling is naast aandacht voor de uitkomst binnen dit niveau aandacht voor het leerproces noodzakelijk. ${ }^{31}$ Naast het organiseren van toetsing moeten wij nadenken over hoe we ervaringen kunnen organiseren en hoe we optimaal gebruik maken van die ervaringen. Een mooi voorbeeld hiervan zijn de debriefing technieken die vanuit de simulatiewereld steeds meer doordringen op de werkplek om kort als team te evalueren wat goed ging en beter kan. ${ }^{32}$ Dit soort leermomenten moeten meetellen in portfolio's, voortgangsgesprekken en opleidingsvisitaties. Dit vraagt om ruimte om je te ontwikkelen zonder dat je wordt afgerekend op leeruitkomst, om legitimering van het leerproces. Opleidingen in de zorg moeten het leerproces centraler stellen, meer inzetten op begeleiding en loslaten dat aan het einde van de opleiding iedereen hetzelfde is en kan. Dat wordt wennen!

Het derde niveau gaat over de ontwikkeling van de zorgverlener als mens. Het vasthouden van die motivatie waarmee bijna iedereen aan een opleiding in de zorg begint, er zijn voor een medemens die hulp nodig heeft. Dit moeten we niet willen vangen in leeruitkomsten, je kan iemand niet bekwaam verklaren op empathie, of op authenticiteit. Dat neemt niet weg dat de ontwikkeling van de humanistische kant van elke zorgverlener essentieel is en dat huidige uitkomst-georiënteerde opleidingsplannen hier onvoldoende aandacht voor hebben. ${ }^{33}$ Elke zorgverlener, verpleegkundige, arts maakt zijn of haar eigen ontwikkeling door. Dat heeft te maken met de dingen die je meemaakt in je werk, welke normen en waarden vaak onbewust worden bekrachtigd. Daarnaast maken we dingen mee in ons privéleven die beïnvloeden hoe je je als zorgverlener opstelt. ledereen doet dat op z'n eigen manier maar we kunnen dit ondersteunen door bewustwording en reflectie op dit proces. Het vraagt ook om een werk- en leerklimaat waar aandacht is voor humanisme. De manieren om dat te bereiken hebben we nog niet voldoende in de vingers, onderzoek op dit terrein heeft nog een weg te gaan.

Vanuit opleidingen moeten we ons realiseren dat het niet gaat werken in de vorm van toetsbare leeruitkomsten. ledere zorgverlener kiest andere woorden, een ander gebaar, toont betrokkenheid net iets anders. En dat is goed, want patiënten zijn ook allemaal net iets anders en zo kunnen we samen voor iedereen zorgen. Wat we in ieder geval moeten doen is aandacht voor dit leerproces inbouwen in onze opleidingen en werkplekken. 
Om deze visie op work-based medical education te realiseren is vertrouwen nodig. Vertrouwen van de wereld om ons heen dat we in de zorg ons inzicht en ervaring kunnen gebruiken bij opleiden en begeleiden van jonge collega's. Acceptatie dat we sommige aspecten van opleiden en wat dat oplevert transparant kunnen maken, maar niet alles. Het vereist ook dat we als zorgverleners ons best doen onze praktijk te kennen, te weten wanneer zich iets voordoet waar je van zelf kan leren of wat bij kan dragen aan de ontwikkeling van collega's.

Ik vat het nog een keer samen. De uitdaging waar we voor staan is om zorgverleners te leren helen. Om ze zo op te leiden dat ze kennis, vaardigheden en toenemende ervaring in kunnen zetten om zo goed mogelijk bij te dragen aan het proces van helen door een medemens met een hulpvraag. De afgelopen decennia heeft competentiegericht opleiden ons nieuwe manieren gegeven om naar de zorg te kijken en te herkennen wat belangrijk is. Het heeft ons het inzicht gebracht dat er meer nodig is voor goede zorg dan inhoudelijke expertise en er is meer aandacht voor onderwijs en opleiden op de werkvloer. Met de beste bedoelingen zijn we echter terecht gekomen in een lego-wereld van toetsbare bouwstenen die samengevoegd een professional zouden moeten maken, de paradox van competentiegericht opleiden. Dat werkt niet. Het doet geen recht aan wat nodig is om goede zorg te verlenen. We hebben een andere insteek nodig. Ik heb u uitgelegd op welke drie niveaus van ontwikkeling opleidingen in de zorg zich zouden moeten richten. Kennis en vaardigheden, individuele en collectieve competenties en ontwikkeling als mens. Daarbinnen moeten we kiezen welke leeruitkomsten we hard willen toetsen en welke leerprocessen we willen begeleiden. Dan ontstaat een curriculum dat deels vergelijkbaar is tussen individuen en deels uniek, dat niet alleen bijdraagt aan het leren van het individu maar ook aan het functioneren van het collectief. Goede opleiding en goed zorg gaan dan hand in hand.

Tot slot kom ik nog een laatste keer terug op mijn onderzoeksagenda. Door samenwerking tussen verschillende perspectieven vanuit zorg, opleidingen en onderzoek draagt mijn onderzoek bij aan begrijpen hoe zorgverleners leren van het werk dat ze doen én hoe opleidingen leren optimaal kunnen ondersteunen. Ik hoop dat $\mathrm{u}$ nu niet alleen begrijpt waar mijn interesses vandaan komen, maar dat u met mij bij wilt bijdragen aan dit onderzoek om work-based medical education vorm te geven. Onderzoek in professionele silo's, bijvoorbeeld alleen binnen geneeskunde of alleen binnen verloskunde, gaat het antwoord niet geven. In dit kader ben ik erg blij met het succesvolle initiatief van Erik Driessen en mij om in Maastricht een onderzoeksgroep te starten waar psycholoog, bestuurskundige, onderwijskundige, fysiotherapeut en arts bij elkaar komen. We moeten niet bang zijn elkaar op te zoeken. Een angst die helaas bij sommigen wel bestaat. Gelukkig bij velen ook niet en ik blijf op zoek naar nieuwe mogelijkheden voor samenwerking. De boodschap: zoek andere visies op en leer van elkaar.

\section{Dankwoord}

Tijd voor mijn dankwoord. De Stichting Wetenschapsbeoefening van de Universiteit Maastricht en het College van Bestuur van de Universiteit Maastricht wil ik bedanken voor het in mij gestelde vertrouwen en mijn benoeming.

De rest van het dankwoord was lastig om te schrijven. Niet omdat ik niet weet wie ik wil bedanken, maar omdat ik zoveel mensen wil bedanken en dat gaat niet allemaal. lk sta hier dankzij de steun en kansen die velen van jullie mij hebben gegeven. Hier staan is leuk, maar ook erg relatief. lemand steunen in succes in één ding, maar er zijn wanneer het tegenzit is iets anders. Ook dan zijn velen van jullie er. Vandaag leek me een mooi moment om ook daarvoor te bedanken, dus bij deze.

Een paar groepen wil ik in het bijzonder noemen. Collega's uit het VUmc, verpleging, verloskundigen, echoscopisten, secretaresses, arts-assistenten en stafleden. Bedankt voor jullie collegialiteit, vriendschap, kritiek en steun. Ik werk in een team om trots op te zijn. En een 
speciaal woord van dank voor mijn collega's uit de staf verloskunde. Wat ik zojuist noemde over er zijn in voor- en tegenspoed gaat zeker voor jullie op. Bedankt voor de ruimte die ik krijg om mezelf te zijn.

Er zijn hier ook een aantal toekomstige UMCA-collega's, nu nog werkzaam voor het AMC. Dank voor jullie komst en ik kijk ernaar uit samen een team te gaan vormen.

Uiteraard wil ik alle collega's van de vakgroep Onderwijsontwikkeling en -onderzoek en SHE bedanken. Wat mij betreft zijn we allen onderdeel van een zeer succesvolle netwerkorganisatie. Ook al zit ik iets verder weg van de spil hier in Maastricht, ik voel me door jullie altijd volledig onderdeel van onze gezamenlijke inspanning om medisch onderwijs en onderzoek daarnaar verder te helpen. Erik in het bijzonder. Het is geweldig om samen op te kunnen trekken.

In aanloop naar vandaag hebben Irma, Christine, Lilian, Petra, Chris en Jessica geholpen met alle voorbereidingen. Dank jullie wel.

Zoals genoemd werk ik in mijn onderzoek met veel mensen samen. De promovendi zijn daarin voor mij erg bijzonder. Ik vind het echt een eer om een aantal jaar, maar liever niet meer dan 4 , bij te mogen dragen aan iemands wetenschappelijke en vaak ook persoonlijke reis door het landschap van medisch onderwijskundig onderzoek. Daarvoor wil ik jullie allemaal hartelijk bedanken.

En dan het illustere duo dat Fedde wist te strikken voor de begeleiding van mijn eigen proefschrift: Cees en Albert. Of het nou gaat over onderzoek doen, begeleiden, mentor zijn of je weg vinden in bestuur en management, jullie zijn al 13 jaar mijn referentiepunt. Bedankt.

Christianne. Jou wil ik apart bedanken voor de onvoorwaardelijke steun die ik van je krijg als afdelingshoofd Verloskunde en Gynaecologie in het VUmc en ook voor je vriendschap. Jij zag direct de meerwaarde van de niet alledaagse combinatie van mijn werk in Amsterdam en Maastricht en maakt dit mede mogelijk.

Fedde. Je bent iemand om naar op te kijken, letterlijk en figuurlijk. Ik ben er trots op hier te staan als je eerste promovendus en als eerste hoogleraar van al je promovendi. Dat we samen onderzoek zijn blijven doen is een groot plezier. Mooier nog is de vriendschap die we hebben. Dank je wel.

Mam. Jij hebt de basis gelegd voor wie ik nu ben. Dank je daarvoor.

En Jessica. Ik bewonder je om de manier waarop je het leven neemt zoals het komt. Hoe je geniet van de mooie dingen en hoe je tegenslagen te boven komt. Bedankt voor de vrijheid die je me gunt. Ik kijk uit naar nog veel moois met elkaar en Thomer.

Ik heb gezegd.

Maastricht, 2 februari 2018 


\section{Referenties}

1. Billett S. Learning through health care work: premises, contributions and practices. Med Educ. 2016 Jan;50(1):124-31.

2. Westerman M. Mind the gap; the transition to hospital consultant. Vrije Universiteit Amsterdam; 2012.

3. van der Leeuw RM, Teunissen PW, van der Vleuten CPM. Broadening the Scope of Feedback to Promote Its Relevance to Workplace Learning. Acad Med. 2017 Oct $24 ; 1$.

4. Teunissen PW. Experience, trajectories, and reifications: an emerging framework of practice-based learning in healthcare workplaces. Adv Heal Sci Educ. 2015 Oct 1;20(4):843-56.

5. Expert Panel Convened by The National Patient Safety Foundation. Free from Harm. Boston, MA; 2015.

6. Corallo AN, Croxford R, Goodman DC, Bryan EL, Srivastava D, Stukel T a. A systematic review of medical practice variation in OECD countries. Health Policy. 2014 Jan;114(1):5-14.

7. Morcke AM, Dornan T, Eika B. Outcome (competency) based education: An exploration of its origins, theoretical basis, and empirical evidence. Adv Heal Sci Educ. 2013 Oct 18;18(4):851-63.

8. Scheele F, Teunissen P, Van LS, Heineman E, Fluit L, Mulder H, et al. Introducing competency-based postgraduate medical education in the Netherlands. Med Teach. 2008;30(1466-187X (Electronic) LA-eng PT-Journal Article SB-IM):248-53.

9. Fokkema J. Innovating the practice of medical specialty training. Vrije Universiteit Amsterdam; 2014.

10. Bok H. Competency-based veterinary education An integrative approach to learning and assessment in the clinical workplace. Universiteit Utrecht; 2014.

11. van Loon KA, Teunissen PW, Driessen EW, Scheele F. The Role of Generic Competencies in the Entrustment of Professional Activities: A Nationwide Competency-Based Curriculum Assessed. J Grad Med Educ. 2016;8(4):546-52.

12. Van Merriënboer JJG, Van Der Klink MR, Hendriks M. Competenties : Van Complicaties Tot Compromis. Over schuifjes en begrenzers. Den Haag; 2002.

13. Frank JR, Danoff D. The CanMEDS initiative: implementing an outcomes-based framework of physician competencies. MedTeach. 2007 Sep;29(1466-187X (Electronic) LA-eng PT-Journal Article SB-IM):642-7.

14. Denton H. Doctors Striking in Toronto. The Washington Post. 1986.

15. Neufeld V, Maudsley R, Pickering R, Turnbull J, Weston W, Brown M, et al. Educating Future Physicians for Ontario. Acad Med. 1993;73(11):1133-48.

16. Gadamer H-G. The enigma of health : the art of healing in a scientific age. Stanford University Press; 1996. 180 p.

17. CanMEDS [Internet]. Royal College of Physicians and Surgeons of Canada. 2015. Available from: http://canmeds.royalcollege.ca

18. Johnston B. Summative Assessment of Portfolios: An Examination of Different Approaches to Agreement over Outcomes. Stud High Educ. 2004;29(3):395-412.

19. Bindal T, Wall D, Goodyear HM. Trainee doctors' views on workplace-based assessments: Are they just a tick box exercise? Med Teach. 2011;33(11):919-27.

20. Massie J, Ali JM. Workplace-based assessment: a review of user perceptions and strategies to address the identified shortcomings. Adv Heal Sci Educ. 2015;

21. Bok HG, Teunissen PW, Favier RP, Rietbroek NJ, Theyse LF, Brommer H, et al. Programmatic assessment of competency-based workplace learning: when theory meets practice. BMC Med Educ. 2013 Sep 11;13(1):123.

22. ten Cate $\mathrm{O}$, Scheele $\mathrm{F}$. Competency-based postgraduate training: can we bridge the gap between theory and clinical practice? AcadMed. 2007 Jun;82:542-7.

23. Jarvis-Selinger S, Pratt DD, Regehr G. Competency Is Not Enough. Acad Med. 2012 Sep;87(9):1185-90. 
24. Lingard L. Paradoxical Truths and Persistent Myths. J Contin Educ Health Prof. 2016;36:S19-21.

25. Goldszmidt M, Dornan T, Lingard L. Progressive collaborative refinement on teams: implications for communication practices. Med Educ. 2014 Mar;48(3):301-14.

26. Eraut M. Informal learning in the workplace. Stud Contin Educ. 2004;26(2):247-73.

27. Eraut M, Alderton J, Cole G, Senker P. The development of knowledge and skills at work. In: Coffield F, editor. Differing visions of a Learning Society Vol I. Bristol: Policy Press; 2000. p. 231-62.

28. van der Vleuten CPM, Schuwirth LWT, Scheele F, Driessen EW, Hodges B. The assessment of professional competence: building blocks for theory development. Best Pract Res Clin Obstet Gynaecol. 2010 Dec;24(6):703-19.

29. Bok HGJ, Jaarsma DADC, Teunissen PW, van der Vleuten CPM, van Beukelen P. Development and validation of a competency framework for veterinarians. J Vet Med Educ. 2011 Jan;38(3):262-9.

30. Salas E, Wilson KA, Burke CS, Wightman DC. Does Crew Resource Management Training Work? An Update, an Extension, and Some Critical Needs. Hum Factors J Hum Factors Ergon Soc. 2006 Jun 14;48(2):392-412.

31. Beckett D. Embodied Competence and Generic Skill: The emergence of inferential understanding. Educ Philos Theory. 2004;36(5):497-508.

32. Schmutz JB, Eppich WJ. Promoting Learning and Patient Care Through Shared Reflection: A Conceptual Framework for Team Reflexivity in Health Care. Acad Med. 2017 Nov;92(11):1555-63.

33. Rider EA, Kurtz S, Slade D, Longmaid HE, Ho MJ, Pun JKH, et al. The international charter for human values in healthcare: An interprofessional global collaboration to enhance values and communication in healthcare. Patient Educ Couns. 2014;96(3):273-80. 